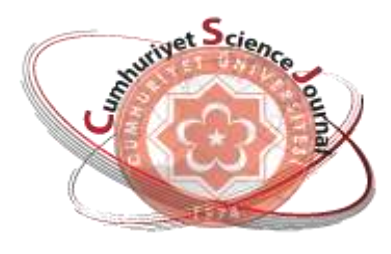

e-ISSN: $2587-246 X$

ISSN: $2587-2680$

\section{Cumburiyet Seionee Journal $\operatorname{csg}$}

Cumhuriyet Sci. J., Vol.39-1(2018) 250-257

\title{
A New Spherical Catalyst for Hydrogen Evolution Reaction
}

\author{
Murat FARSAK \\ Osmaniye Korkut Ata University, Applied Science School of Kadirli, Department of Food Technology, 80000, Osmaniye, \\ TURKEY
}

Received: 07.08.2017; Accepted: 02.03.2018

http://dx.doi.org/10.17776/csj.406167

\begin{abstract}
CuFeZn composite catalysts have been prepared on the graphite electrode by electrochemical deposition as electrocatalytic materials for hydrogen evolution reaction (HER). The etching process was applied on catalysts in caustic solution to leach out zinc and to produce a porous electrocatalytic surface for hydrogen evolution. The surface morphologies were investigated by scanning electron microscopy. HER activity is assessed by recording cathodic current-potential curves, cyclic voltammetry, electrochemical impedance spectroscopy and electrolysis techniques. The results show that etched catalysts have a compact and porous structure as well as a good electrocatalytic activity for the HER in alkaline media.
\end{abstract}

Keywords: Hydrogen evolution, metal deposition, cathode catalyst

\section{Hidrojen İndirgenme Reaksiyonu için Yeni Bir Küresel Katalizör}

Özet: CuFeZn kompozit katalizörleri, hidrojen indirgenme reaksiyonu (HER) için elektrokimyasal malzemeler olarak elektrokimyasal biriktirme ile grafit elektrotu üzerinde hazırlanmıştır. Sodyum hidroksit çözeltideki aşındırma işlemi, çinkoyu yüzeyden uzaklaştırmak ve hidrojen indirgeme için gözenekli bir elektrokatalitik yüzey üretmek için katalizörler üzerinde uygulanmıştır. Yüzey morfolojileri taramalı elektron mikroskobu ile araştırıldı. HER aktivitesi katodik akım-potansiyel eğrileri, dönüşümlü voltametri, elektrokimyasal impedans spektroskopisi ve elektroliz teknikleri kullanılarak değerlendirildi. Sonuçlar, aşındırılmış katalizörlerin, alkali ortamlarda HER için iyi bir elektrokatalitik aktivitenin yanı sıra, kompakt ve gözenekli bir yapıya sahip olduğunu göstermektedir.

Anahtar Kelimeler: Hidrojen indirgenme reaksiyonu, metal biriktirme, katot katalizörü

\section{INTRODUCTION}

Conventional energy sources such as coal, natural gas, and oil are running out of day by day. Due to the size of this depletion, humanity is looking for alternative energy sources [1]. Hydrogen is now considered as one of the alternative energy materials of future. It has the highest chemical energy per unit mass. It is a clean fuel that does not release greenhouse gases and other harmful gases during the energy production process. Although there are various methods for producing hydrogen, these methods emit carbon dioxide because they use fossil fuels or hydrocarbons based raw materials. One of the alternative methods not producing carbon dioxide emissions during the hydrogen production process is water electrolysis. This process splits water into hydrogen atoms using electric energy by electrochemical method. The advantage of this method is that it uses water as raw material. Because water is a relatively unlimited source and is found almost everywhere on the earth. However, hydrogen 
production by water electrolysis is expensive due to high cost and energy consumption [2]. These disadvantages can be reduced by using cheap electrode materials with high electrocatalytic activity.

Carbon has been used as support material for many years, in different catalytic processes such as a metal catalyst, activated carbon, carbon black, graphite and graphite materials because of its low-cost and natural abundance [3]. In addition to this, the cost of producing electrolytic hydrogen can be reduced by reducing the over voltage of the electrode reactions. According to the electrocatalysis theory, the electrocatalytic activity is related to the adsorption heat of intermediates formed at the electrode surface[4].

Some metals with strong hydrogen bonds such as $\mathrm{Cu}, \mathrm{Fe}$, and $\mathrm{Ni}$ are chosen for catalyst preparation. The efficiency of the electrode materials can be improved by increasing the ratio between the real and geometric surface area of the electrode or by a synergistic combination of electrocatalytic components [5].

A significant advance in the protective properties of zinc coatings can be achieved by co-deposition of metals such as $\mathrm{Co}, \mathrm{Ni}, \mathrm{Fe}$ and Mn [6-8]. Among these elements, iron provides improved corrosion resistance and weldability. Because of better mechanical properties and high corrosion resistance, ternary alloy coatings are better than binary zinc alloy coatings [9]. In addition, iron is one of the most commonly found elements in the world [10].

One of the most commonly used methods for producing electrocatalyst is electrodeposition technique because of its simplicity and low cost $[11,12]$. The etching process by $\mathrm{NaOH}$ of the zinc-based alloys is widely used in the literature. The catalyst acquires a porous structure through the etching process. Furthermore, the obtained catalysts by using this technique have a large surface area and high catalytic activity. [13-21].

In this study, copper, iron, and zinc species were electrodeposited on the graphite electrode to investigate electrocatalytic activity for HER.
Surface structures of the catalysts were characterized by scanning electron microscopy (SEM) technique. The catalytic activities were analyzed by cyclic voltammetry (CV), electrochemical impedance spectroscopy (EIS) and cathodic polarization techniques.

\section{Experimental:}

The working electrode was a cylindrical disc cut from a graphite rod in about $5 \mathrm{~cm}$ length. The graphite rod was coated with a polyester block, aspect for measurement area of $0.283 \mathrm{~cm}^{2}$ and the electrical conductivity was provided by a copper wire. Before electrodeposition, the open surfaces of the graphite rods were polished with emery paper (320-1200 grain). Then the electrodes were washed with distilled water, thoroughly degreased with ethanol, followed washed with distilled water again and immersed in the bath solution.

The electrodeposition of the copper-iron-zinc coating was performed galvanostatically using a direct current power supply instrument (TT Technic-YH-303D). The counter electrode was the platinum sheet, which has a $2 \mathrm{~cm}^{2}$ surface area. The electrodes were coated in a bath solution mixed at a constant speed at room temperature. Copper-iron-zinc was coated on the graphite surface by a constant current density of $15 \mathrm{~mA} \mathrm{~cm}{ }^{-2}$ during $2700 \mathrm{~s}$. All the bath compositions were given in Table 1. Copper, iron and zinc baths were prepared one by one, and to obtain $\mathrm{Cu} / \mathrm{Fe}_{2 \mathrm{x}} \mathrm{Zn}_{\mathrm{x}}$ and $\mathrm{Cu} / \mathrm{Fe}_{2 \mathrm{x}} \mathrm{Zn}_{2 \mathrm{x}}$ baths, different volumes of $\mathrm{Cu}, \mathrm{Fe}$, and $\mathrm{Zn}$ baths were mixed in a beaker according to the Table 1 , and then the electrodes were coated. After deposition, the electrodes were rinsed with distilled water to remove residues of bath chemicals. The electrodes were first treated with 1.0 $\mathrm{M} \mathrm{NaOH}$ for one hour until the dissolution rate of $\mathrm{Zn}$ decreased. Then they were exposed to $30 \% \mathrm{NaOH}$ solution at room temperature for 3 hours and washed with double distilled water. The obtained electrode called as $\mathrm{Cu} @ \mathrm{Fe}_{\mathrm{x}} \mathrm{Zn}_{2 \mathrm{x}}$. All used chemicals, which were purchased from Merck Millipore Co., Ltd. Germany, were of analytical or chemical grade purity. 
Table 1. Bath Compositions.

\begin{tabular}{lc}
\hline Bath Name & \multicolumn{1}{c}{ Bath Composition } \\
\hline $\mathbf{C u}$ & $27.72 \mathrm{~g} \mathrm{CuSO}_{4} \cdot 5 \mathrm{H}_{2} \mathrm{O}$ and $1.25 \mathrm{~g} \mathrm{H}_{3} \mathrm{BO}_{3}$ for $100 \mathrm{ml}$ \\
$\mathbf{F e}$ & $30.86 \mathrm{~g} \mathrm{FeSO}_{4} \cdot 7 \mathrm{H}_{2} \mathrm{O}$ and $1.25 \mathrm{~g} \mathrm{H}_{3} \mathrm{BO}_{3}$ for $100 \mathrm{ml}$ \\
$\mathbf{Z n}$ & $31.92 \mathrm{~g} \mathrm{ZnSO}_{4} \cdot 7 \mathrm{H}_{2} \mathrm{O}$ and $1.25 \mathrm{~g} \mathrm{H}_{3} \mathrm{BO}_{3}$ for $100 \mathrm{ml}$ \\
$\mathbf{C u} / \mathbf{F e}_{2 x} \mathbf{Z n}_{\mathbf{x}}$ & $10 \mathrm{ml} \mathrm{Cu}$ bath, $20 \mathrm{ml} \mathrm{Fe}$ bath and $10 \mathrm{ml} \mathrm{Zn} \mathrm{bath}$ \\
$\mathbf{C u} / \mathbf{F e}_{x} \mathbf{Z n}_{2 x}$ & $10 \mathrm{ml} \mathrm{Cu}$ bath, $10 \mathrm{ml} \mathrm{Fe}$ bath and $20 \mathrm{ml} \mathrm{Zn} \mathrm{bath}$ \\
\hline
\end{tabular}

The electrochemical measurements were performed galvanostatically using Potentiostatgalvanostat (Gamry Interface 1000) with a threeelectrode configuration. The platinum electrode with a surface area of $2 \mathrm{~cm}^{2}$ and $\mathrm{Ag} / \mathrm{AgCl}(3 \mathrm{M}$ $\mathrm{KCl})$ were used as a counter and a reference electrode, respectively. The electrochemical tests were carried out in $1.0 \mathrm{M} \mathrm{KOH}$ solution. The surface morphologies were investigated by scanning electron microscopy (SEM) technique. The electrochemical impedance spectroscopy (EIS) experiments were performed in the frequency range from $10^{6}$ to $0.01 \mathrm{~Hz}$. The amplitude was $0.005 \mathrm{~V}$. CVs were recorded at $100 \mathrm{mV} \mathrm{s}^{-1}$ scan rate. The potentiodynamic polarization plots were measured from open circuit potential to cathodic direction with $1 \mathrm{mV}$ $\mathrm{s}^{-1}$ scan rate.

The system set up with one burette and two electrodes for the hydrogen evolution measurement (Fig. 1). The 1.0 M KOH solution was used as the electrolyte. The platinum sheet was used as an anode electrode. The initial volume was recorded and $30 \mathrm{~mA} \mathrm{~cm}{ }^{-2}$ constant current density was applied to electrodes during $1 \mathrm{~h}$, and the volume of hydrogen gas evolution was monitored by the volume change from the level of the solution at room temperature. The hydrogen gas and water vapor were measured in the burette as the total volume under these conditions. The hydrogen volumes were calculated with water vapor correction.

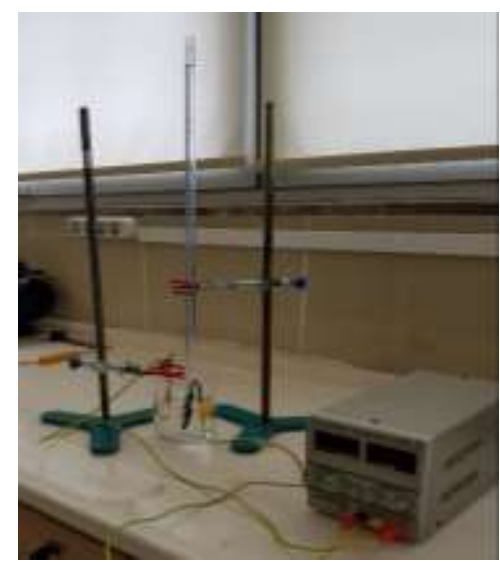

Figure 1. Electrolysis cell system set up.

\section{RESULTS and DISCUSSIONS}

The cyclic voltammograms of $\mathrm{Cu} / \mathrm{Fe}_{2 \mathrm{x}} \mathrm{Zn}_{\mathrm{x}}$, $\mathrm{Cu} / \mathrm{Fe}_{\mathrm{x}} \mathrm{Zn}_{2 \mathrm{x}}$, and $\mathrm{Cu} @ \mathrm{Fe}_{\mathrm{x}} \mathrm{Zn}_{2 \mathrm{x}}$ electrodes obtained in $1.0 \mathrm{M} \mathrm{KOH}$ at $100 \mathrm{mV} \mathrm{s}^{-1}$ scan rate and room temperature were given in Fig 2 . The raised amount of zinc showed a slight increase in peak potentials. After the etching of the $\mathrm{Cu} / \mathrm{FexZn2x}$ electrode exhibited a significant enhancement in peak currents because of the increased surface area. 


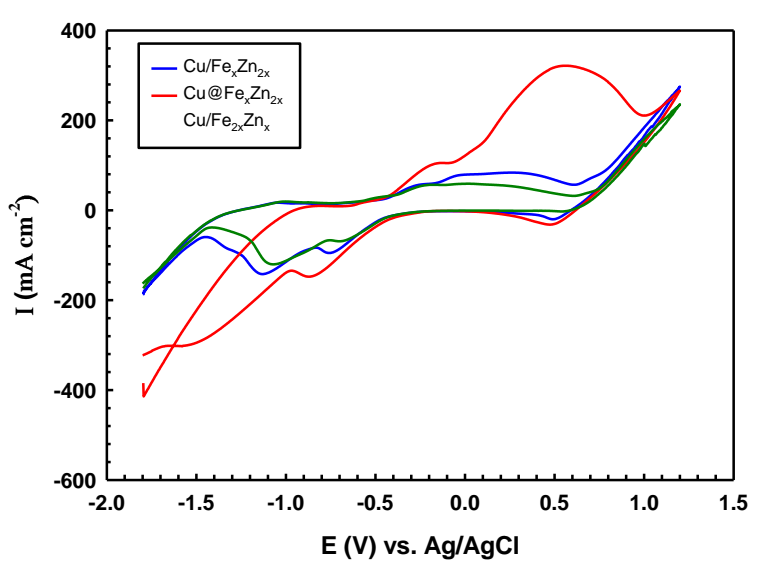

Figure 2. The cyclic voltammograms of $\mathrm{Cu} / \mathrm{Fe}_{2 x} \mathrm{Zn}_{\mathrm{n}}$, $\mathrm{Cu} / \mathrm{Fe}_{\mathrm{x}} \mathrm{Zn}_{2 \mathrm{x}}$, and $\mathrm{Cu} @ \mathrm{Fe}_{\mathrm{x}} \mathrm{Zn}_{2 \mathrm{x}}$ electrodes obtained in $1.0 \mathrm{M}$ $\mathrm{KOH}$ at $100 \mathrm{mV} \mathrm{s}^{-1}$ scan rate and room temperature.

It was observed that reduction peaks at $-1.15 \mathrm{~V}$, $-0.78 \mathrm{~V}$ and $0.47 \mathrm{~V}$ for $\mathrm{Zn}^{+2} / \mathrm{Zn}^{+}, \mathrm{Fe}^{+2} / \mathrm{Fe}^{+}$and $\mathrm{Cu}^{+2} / \mathrm{Cu}^{+}$conversion peaks at cathodic direction. Zinc reduction was observed at $-1.15 \mathrm{~V}$ in the electrodes which the etching process was not applied, and zinc peaks were observed to disappear after the etching process. Which explains that the zinc is removed from the surface during the etch process and enlarges the surface area by forming a recessed protruding structure in this way. The electrode, which was applied etching process, has shown high catalytic efficiency in comparison with the others.

Figure 3 shows the Nyquist and phase angle diagrams obtained by applying $5 \mathrm{mV}$ amplitude in the frequency range of $10^{6} \mathrm{~Hz}$ to $0.01 \mathrm{~Hz}$ in 1.0 M KOH solution of $\mathrm{Cu} / \mathrm{Fe}_{2 \mathrm{x}} \mathrm{Zn}_{\mathrm{x}}, \mathrm{Cu} / \mathrm{Fe}_{\mathrm{x}} \mathrm{Zn}_{2 \mathrm{x}}$, and $\mathrm{Cu} @ \mathrm{Fe}_{\mathrm{x}} \mathrm{Zn}_{2 \mathrm{x}}$ electrodes. Within each of the three electrodes, one in the high-frequency region and one in the low-frequency region, a total of two-time constants are observed. These two-time constants are clearly visible in the phase angle-frequency curve. The capacitive time constant in the high-frequency region of the Nyquist diagram shows the charge transfer resistance while the linear inductive time constant in the low-frequency region indicates that the hydrogen production is diffusion controlled. Compared with the charge transfer resistances, the $\mathrm{Cu} @ \mathrm{Fe}_{\mathrm{x}} \mathrm{Zn}_{2 \mathrm{x}}$ electrode which is exposed to etch process shows lower impedance value than other electrodes. When the inductance time constants are compared, the order of the linear part is $\mathrm{Cu} / \mathrm{Fe}_{2 \mathrm{x}} \mathrm{Zn}_{\mathrm{x}}>\mathrm{Cu} / \mathrm{Fe}_{\mathrm{x}} \mathrm{Zn}_{2 \mathrm{x}}>$ $\mathrm{Cu} @ \mathrm{Fe}_{\mathrm{x}} \mathrm{Zn}_{2 \mathrm{x}}$. This sequence shows that the most catalytically active electrode is the etch-treated electrode. These results demonstrate that increasing surface area with the etch process linearly affects the catalytic activity [15].
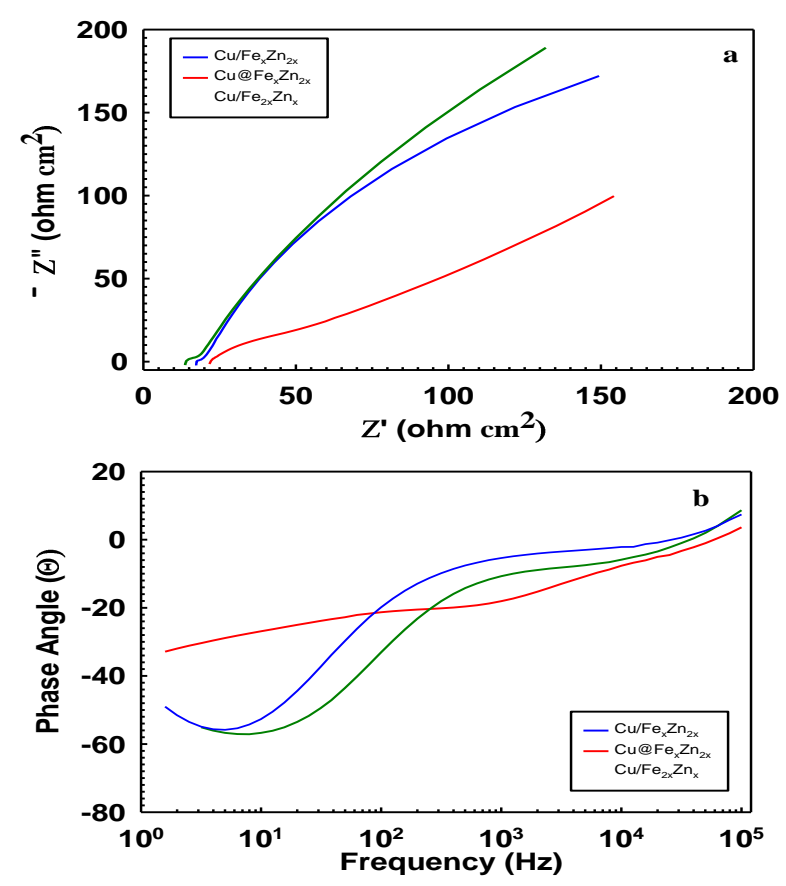

Figure 3. Nyquist (a) and Phase angle (b) plots for $\mathrm{Cu} / \mathrm{Fe}_{2 \mathrm{x}} \mathrm{Zn}_{\mathrm{x}}, \mathrm{Cu} / \mathrm{Fe}_{\mathrm{x}} \mathrm{Zn}_{2 \mathrm{x}}$, and $\mathrm{Cu} @ \mathrm{Fe}_{\mathrm{x}} \mathrm{Zn}_{2 \mathrm{x}}$ electrodes at room temperature.

Polarization curves of $\mathrm{Cu} / \mathrm{Fe}_{2 \times} \mathrm{Zn}_{\mathrm{x}}, \mathrm{Cu} / \mathrm{Fe}_{\mathrm{x}} \mathrm{Zn}_{2 \mathrm{x}}$, and $\mathrm{Cu} @ \mathrm{Fe}_{\mathrm{x}} \mathrm{Zn}_{2 \mathrm{x}}$ in $1.0 \mathrm{M} \mathrm{KOH}$ solution at $1 \mathrm{mV}$ $\mathrm{s}^{-1}$ scan rate at room temperature are seen in Fig 4. As seen in Fig. 4, over potentials for $\mu_{10}$ values are $-1.2023 \mathrm{~V},-1.1902 \mathrm{~V}$, and $-1.1404 \mathrm{~V}$ for $\mathrm{Cu} / \mathrm{Fe}_{2 \mathrm{x}} \mathrm{Zn}_{\mathrm{x}}, \quad \mathrm{Cu} / \mathrm{Fe}_{\mathrm{x}} \mathrm{Zn}_{2 \mathrm{x}}, \quad$ and $\mathrm{Cu} @ \mathrm{Fe}_{\mathrm{x}} \mathrm{Zn}_{2 \mathrm{x}}$ electrodes, respectively. $\mathrm{Cu} @ \mathrm{Fe}_{\mathrm{x}} \mathrm{Zn}_{2 \mathrm{x}}$ has the lowest over potential for each current. This phenomenon is clarifying that the $\mathrm{Cu} @ \mathrm{Fe}_{\mathrm{x}} \mathrm{Zn}_{2 \mathrm{x}}$ electrode has the most catalytic efficiency. 


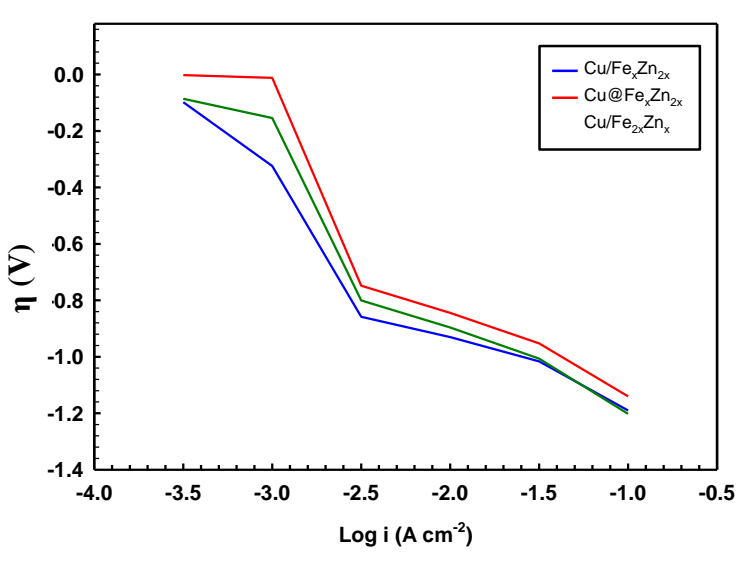

Figure 4. Polarization curves of $\mathrm{Cu} / \mathrm{Fe}_{2 x} \mathrm{Zn}_{\mathrm{x}}, \mathrm{Cu} / \mathrm{Fe}_{\mathrm{x}} \mathrm{Zn} 2 \mathrm{x}$, and $\mathrm{Cu} @ \mathrm{Fe}_{\mathrm{x}} \mathrm{Zn}_{2 \mathrm{x}}$ in $1.0 \mathrm{M} \mathrm{KOH}$ solution at $1 \mathrm{mV} \mathrm{s}^{-1}$ scan rate at room temperature.

The dissociative adsorption of water molecules plays an important role in the mechanism and kinetics of hydrogen generation from alkaline solutions. Generally, the hydrogen evolution mechanism in alkaline solution proceeds by the Volmer reaction. This step is followed by Heyrovsky or Tafel reaction [15].

When the Tafel slope is about $120 \mathrm{mV} \mathrm{dec}^{-1}, 40$

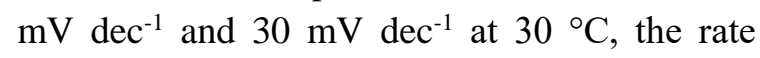
determining step (rds) for HER are accepted as Volmer, Heyrovsky and Tafel reaction step, respectively [22-24].

The Tafel slope which was calculated as $492 \mathrm{mV}$ dec-1 from the polarization curve of $\mathrm{Cu} @ \mathrm{Fe}_{\mathrm{x}} \mathrm{Zn}_{2 \mathrm{x}}$ is higher than $120 \mathrm{mV} \mathrm{dec}{ }^{-1}$. This value should be explained by a thin layer of $\mathrm{Fe}$ oxide. Because the thin Fe-oxide layer on the surface behaves as a semiconductor, deviation from the Tafel curve value is seen [15].

Fe-oxide's electronic conductivity is lower than metallic Fe. The decrease in symmetry factor, $\beta$, and the increase in Tafel slope does not change the reaction mechanism. In the Volmer step as the rds, the symmetry factor, $\beta$, equals the transfer coefficient $\alpha(\alpha=\beta)$.

$$
\alpha=\frac{2.303 \times R \times T}{b \times n \times F}
$$

where $\mathrm{T}$ is the thermodynamic temperature $(\mathrm{K})$, $\mathrm{F}(96,487 \mathrm{C}$ mol-1) is Faraday constant, $\mathrm{n}$ is the number of electrons exchanged, and $\mathrm{R}$ is (8.314 $\mathrm{J} \mathrm{mol}^{-1} \mathrm{~K}^{-1}$ ) is gas constant. The thin oxide layer, which exceeds the low electron transfer barrier, deposited on the Fe surface. This gives a lower transfer coefficient value, $\alpha_{F e}=\beta_{F e}=0.120$.

SEM micrographs of $\mathrm{Cu} / \mathrm{Fe}_{\mathrm{x}} \mathrm{Zn}_{2 \mathrm{x}}, \mathrm{Cu} / \mathrm{Fe}_{2 \mathrm{x}} \mathrm{Zn}_{\mathrm{x}}$, and $\mathrm{Cu} @ \mathrm{Fe}_{\mathrm{x}} \mathrm{Zn}_{2 \mathrm{x}}$ are given in Fig 5. When the micrograph taken from the surface of the $\mathrm{Cu} / \mathrm{Fe}_{\mathrm{x}} \mathrm{Zn}_{2 \mathrm{x}}$ electrode is examined, it is observed that spheres having the smallest average size of $\sim 6 \mu \mathrm{m}$ and the largest average size of $\sim 90 \mu \mathrm{m}$ are formed on the surface (Fig 5a). The gaps between the spheres vary between about 6 and $20 \mu \mathrm{m}$. In Fig. 5b, the reduction in the amount of zinc was caused the reduction of the sphere size, reduced the porosity on the surface and covered by a layer of crystal-like structure on the electrode. The largest sphere that accumulates on the surface of this electrode has an average diameter of $42 \mu \mathrm{m}$. As far as we can see from the comparison of Fig. 5a and b, it is seen that the spherical formation on the surface is welded due to the zinc. In Fig. 5c, although the spheres, which same size and shape with 5a, formed on the surface. Due to the etching process, the distances between the spheres on the surface were increased and the electrode had a wider surface area. 

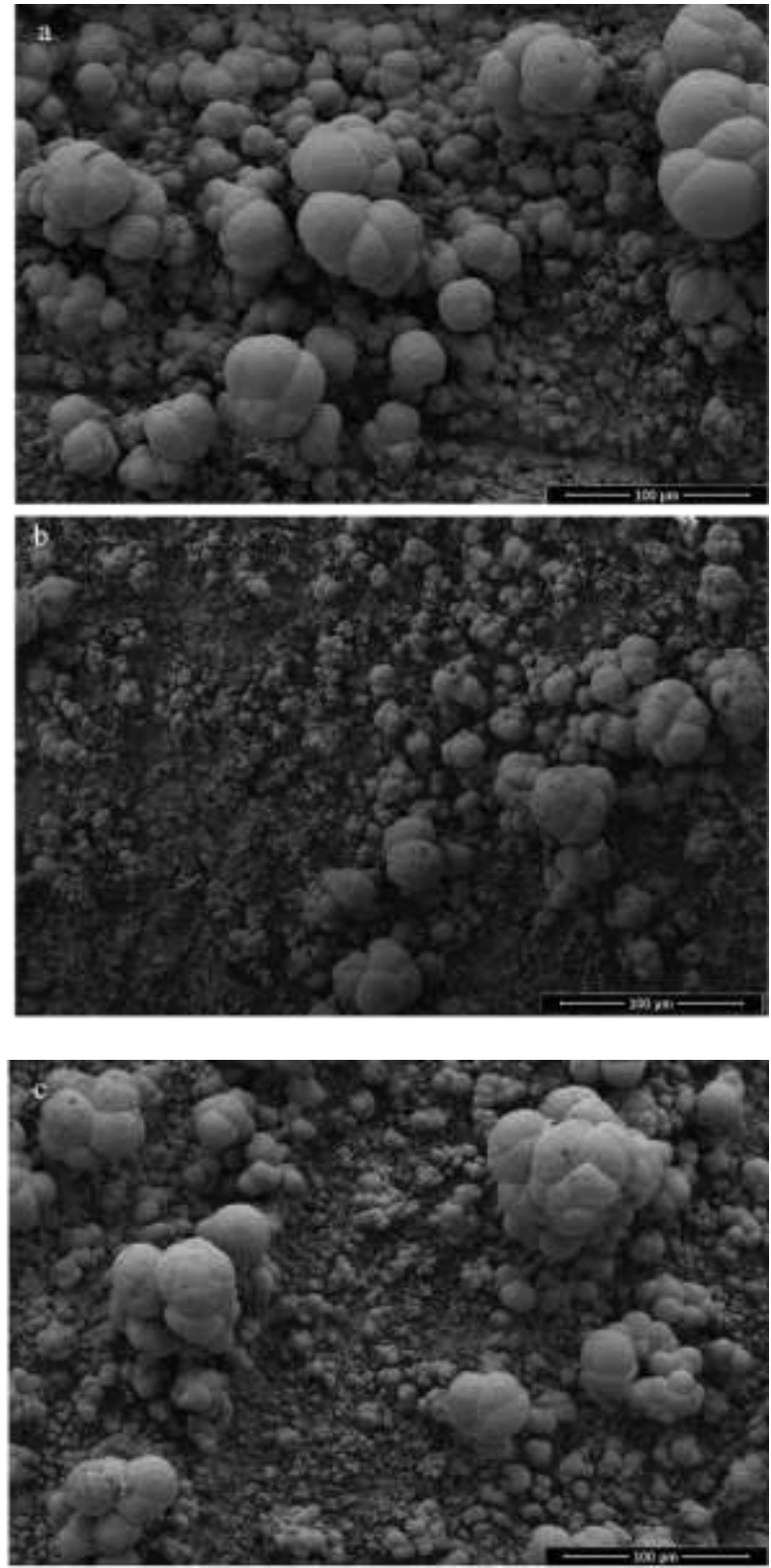

Figure 5. SEM micrographs of $\mathrm{Cu} / \mathrm{Fe}_{x} \mathrm{Zn}_{2 \mathrm{x}}$ (a), $\mathrm{Cu} / \mathrm{Fe}_{2 x} \mathrm{Zn}_{\mathrm{x}}$ (b), and $\mathrm{Cu} @ \mathrm{Fe}_{\mathrm{x}} \mathrm{Zn}_{2 \mathrm{x}}$ (c).

The electrodes which immersed in a $1.0 \mathrm{M} \mathrm{KOH}$ solution in a current of $30 \mathrm{~mA} \mathrm{~cm}{ }^{-2}$ for 1 hour were used to determine the volume of hydrogen as a cathode. At the end of 1 hour, the volume of the accumulated gas from the burette was determined by adjusting the volume originating from water vapor using the room temperature and pressure values. The measured hydrogen volumes for each electrode are given in Table 2 . As it can be understood from the table, the $\mathrm{Cu} @ \mathrm{Fe}_{\mathrm{x}} \mathrm{Zn}_{2 \mathrm{x}}$ electrode produced the most hydrogen at the end of 1 hour. The metalhydrogen bond strength of zinc metal is weaker than iron and copper [25]. Increasing the amount of zinc facilitated the release of hydrogen. After the etching process, the surface area increases with decreasing zinc amount. This is also explained by the fact that the overvoltage values calculated from the potentiodynamic polarization curve are the lowest.

Table 2. Hydrogen gas volumes produced on preparing electrodes by electrolysis technique.

\begin{tabular}{lc}
\hline Cathode & $\mathbf{V}_{\mathbf{H} 2}\left(\mathbf{m L ~ c m}^{-2}\right)$ \\
\hline $\mathbf{C u} / \mathbf{F e}_{2 \times} \mathbf{Z n} \mathbf{n}_{\mathbf{x}}$ & 80.6 \\
$\mathbf{C u} / \mathbf{F e}_{\mathbf{x}} \mathbf{Z n}_{2 \mathbf{x}}$ & 97.5 \\
$\mathbf{C u} @ \mathbf{F e}_{\mathbf{x}} \mathbf{Z n} \mathbf{n}_{\mathbf{2}}$ & 106.0 \\
\hline
\end{tabular}

\section{CONCLUSIONS}

The $\mathrm{Cu} / \mathrm{Fe}_{\mathrm{x}} \mathrm{Zn}_{2 \mathrm{x}}, \mathrm{Cu} / \mathrm{Fe}_{2 \mathrm{x}} \mathrm{Zn}_{\mathrm{x}}$, and $\mathrm{Cu} @ \mathrm{Fe}_{\mathrm{x}} \mathrm{Zn}_{2 \mathrm{x}}$ electrodes were prepared and analyzed for potential use for hydrogen evolution reaction.

$>\quad \mathrm{The} \mathrm{Cu} @ \mathrm{Fe}_{\mathrm{x}} \mathrm{Zn}_{2 \mathrm{x}}$ electrode was found to be catalytically active for hydrogen production, based on the results obtained using CV, EIS, and potentiodynamic polarization curve methods.

$>$ According to the SEM images taken from the electrode surfaces, while the increase in the amount of zinc causes the growth of the spherical layer, the surface is enlarged and the electrode area is increased by the etch process applied afterward.

$>$ When the hydrogen volumes obtained from the electrolysis cell are compared, the most efficient electrode seems to be $\mathrm{Cu} @ \mathrm{Fe}_{\mathrm{x}} \mathrm{Zn}_{2 \mathrm{x}}$.

Given these results, the $\mathrm{Cu} @ \mathrm{Fe}_{\mathrm{x}} \mathrm{Zn}_{2 \mathrm{x}}$ electrode is suitable for use as a catalyst for hydrogen production.

\section{Acknowledgements}

The author is greatly thankful to Çukurova University. The author would like to especially 
thank to Prof.Dr. Gülfeza Kardaş and Asst.Prof.Dr. Esra Telli for their help.

\section{REFERENCES}

[1]. Bicer Y., Chehade G., Dincer I., Experimental investigation of various copper oxide electrodeposition conditions on photoelectrochemical hydrogen production, Int. J. Hydrogen Energy, 42 (2017) 6490-6501.

[2]. Ngamlerdpokin K., Tantavichet N., Electrodeposition of nickel-copper alloys to use as a cathode for hydrogen evolution in an alkaline media, Int. J. Hydrogen Energy, 39 (2014) 25052515.

[3]. Telli E., Döner A., Kardaş G., Electrocatalytic oxidation of methanol on $\mathrm{Ru}$ deposited NiZn catalyst at graphite in alkaline medium, Electrochim. Acta, 107 (2013) 216224.

[4]. Parsons R., The rate of electrolytic hydrogen evolution and the heat of adsorption of hydrogen, Transactions of the Faraday Society, 54 (1958) 1053-1063.

[5]. Crnkovic F., Machado S., Avaca L., Electrochemical and morphological studies of electrodeposited $\mathrm{Ni}-\mathrm{Fe}-$ $\mathrm{Mo}-\mathrm{Zn}$ alloys tailored for water electrolysis, Int. J. Hydrogen Energy, 29 (2004) 249-254.

[6]. Mouanga M., Puiggali M., Devos O., EIS and LEIS investigation of aging low carbon steel with $\mathrm{Zn}-\mathrm{Ni}$ coating, Electrochim. Acta, 106 (2013) 82-90.

[7]. Ortiz-Aparicio J., Meas Y., Trejo G., Ortega R., Chapman T., Chaînet E., Ozil P., Electrodeposition of zinccobalt alloy from a complexing alkaline glycinate bath, Electrochim. Acta, 52 (2007) 4742-4751.

[8]. Szczygieł B., Laszczyńska A., Tylus W., Influence of molybdenum on properties of $\mathrm{Zn}-\mathrm{Ni}$ and $\mathrm{Zn}-\mathrm{Co}$ alloy coatings, Surf. Coat. Technol., 204 (2010) 1438-1444.
[9]. Winiarski J., Tylus W., Krawczyk M., Szczygieł B., The influence of molybdenum on the electrodeposition and properties of ternary $\mathrm{Zn}-\mathrm{Fe}-\mathrm{Mo}$ alloy coatings, Electrochim. Acta, 196 (2016) 708-726.

[10]. Golvano-Escobal I., Suriñach S., Baró M.D., Pané S., Sort J., Pellicer E., Electrodeposition of sizeable and compositionally tunable rhodium-iron nanoparticles and their activity toward hydrogen evolution reaction, Electrochim. Acta, 194 (2016) 263275.

[11]. Safizadeh F., Ghali E., Houlachi G., Electrocatalysis developments for hydrogen evolution reaction in alkaline solutions-a review, Int. J. Hydrogen Energy, 40 (2015) 256-274.

[12]. Sequeira C., Santos D., Brito P., Electrocatalytic activity of simple and modified $\mathrm{Fe}-\mathrm{P}$ electrodeposits for hydrogen evolution from alkaline media, Energy, 36 (2011) 847-853.

[13]. Döner A., Solmaz R., Kardaş G., Enhancement of hydrogen evolution at cobalt-zinc deposited graphite electrode in alkaline solution, Int. J. Hydrogen Energy, 36 (2011) 73917397.

[14]. Döner A., Solmaz R., Kardaş G., Fabrication and characterization of alkaline leached $\mathrm{CuZn} / \mathrm{Cu}$ electrode as anode material for direct methanol fuel cell, Energy, 90 (2015) 1144-1151.

[15]. Farsak M., Telli E., Yüce A.O., Kardaş G., The noble metal loading binary iron-zinc electrode for hydrogen production, Int. J. Hydrogen Energy, (2016)

[16]. Solmaz R., Döner A., Doğrubaş M., Erdoğan İ.Y., Kardaş G., Enhancement of electrochemical activity of Raney-type NiZn coatings by modifying with $\mathrm{PtRu}$ binary deposits: Application for alkaline water electrolysis, Int. J. Hydrogen Energy, 41 (2016) 1432-1440.

[17]. Solmaz R., Döner A., Kardaş G., Preparation, characterization and 
application of alkaline leached $\mathrm{CuNiZn}$ ternary coatings for long-term electrolysis in alkaline solution, Int. J. Hydrogen Energy, 35 (2010) 1004510049.

[18]. Solmaz R., Kardaş G., Hydrogen evolution and corrosion performance of NiZn coatings, Energy Convers. Manage., 48 (2007) 583-591.

[19]. Solmaz R., Kardaş G., Electrochemical deposition and characterization of $\mathrm{NiFe}$ coatings as electrocatalytic materials for alkaline water electrolysis, Electrochim. Acta, 54 (2009) 3726-3734.

[20]. Solmaz R., Kardaş G., Fabrication and characterization of NiCoZn-M (M: $\mathrm{Ag}, \mathrm{Pd}$ and $\mathrm{Pt}$ ) electrocatalysts as cathode materials for electrochemical hydrogen production, Int. J. Hydrogen Energy, 36 (2011) 12079-12087.

[21]. Solmaz R., Salc1 A., Yüksel H., Doğrubaş M., Kardaş G., Preparation and characterization of Pd-modified Raney-type NiZn coatings and their application for alkaline water electrolysis, Int. J. Hydrogen Energy, 42 (2017) 2464-2475.

[22]. Kaninski M.P.M., Nikolić V.M., Potkonjak T.N., Simonović B.R., Potkonjak N.I., Catalytic activity of Pt-based intermetallics for the hydrogen production-Influence of ionic activator, Applied Catalysis A: General, 321 (2007) 93-99.

[23]. Navarro-Flores E., Chong Z., Omanovic S., Characterization of $\mathrm{Ni}$, NiMo, NiW and NiFe electroactive coatings as electrocatalysts for hydrogen evolution

in an acidic medium, J. Mol. Catal. A: Chem., 226 (2005) 179-197.

[24]. Yüce A.O., Döner A., Kardaş G., NiMn composite electrodes as cathode material for hydrogen evolution reaction in alkaline solution, Int. J. Hydrogen Energy, 38 (2013) 44664473. 